\title{
Opportunities and challenges for fish culture in Brazilian reservoirs: a review
}

\author{
Oportunidades e desafios para a aquicultura em reservatórios brasileiros: uma revisão
}

\author{
Evoy Zaniboni-Filho ${ }^{1 *}$, Janaína dos Santos Pedron $^{1}$ and Josiane Ribolli ${ }^{1}$
}

${ }^{1}$ Laboratório de Biologia e Cultivo de Peixes de Água Doce, Departamento de Aquicultura, Universidade Federal de Santa Catarina - UFSC, Rodovia Francisco Thomaz dos Santos, 3532, CEP 88066-260, Florianópolis, SC, Brasil

*e-mail: evoy@lapad.ufsc.br

Cite as: Zaniboni-Filho, E., Pedron, J.S. and Ribolli, J. Opportunities and challenges for fish culture in Brazilian reservoirs: a review. Acta Limnologica Brasiliensia, 2018, vol. 30, e302.

Abstract: Aim: Aquaculture plays an important role in the world and in Brazil. Artificial construction of water bodies, such as ponds and reservoirs, has allowed for fish culture in cages in those environments, generating conflicts over the use of these public waters. The producers are seeking to increase production, and the ecosystem is susceptible to the impacts caused by production activity. The aim of this review was to identify questions about these conflicts (productivity $\times$ environment) and to indicate possible solutions to the main problems related to fish farming in reservoirs. Methods: A bibliographical survey was carried out on the main aspects of cage fish farming in Brazilian reservoirs. Studies from 1977 to 2018 (scientific journals, books, and thesis) were revised using seven databases, the CAPES periodicals portal and Google Scholar websites. The main keywords used were "aquaculture", "reservoir", "cage", "eutrophication", "carrying capacity", "impacts", "oligotrophic", "escapes", "hybrids", and "pollution". Results: We accessed approximately 330 and cited 151 documents. Conclusions: The negative aspects associated with cage fish farming, as escapes of cultivated fish, and the possible solutions of this and others negative impacts were addressed, identifying mechanisms for reducing conflicts between environmental impacts and aquaculture production. Potential solutions include the use of native fish species or sterile species, implementation of monitoring systems of the surrounding area, adoption of measures to reduce the accidental escape of fish, use of multitrophic culture systems, use of highly digestible diets with appropriate food management, and use of computer programs that incorporate current and historical environmental data to calculate carrying capacity and choose the most appropriate location for production.

Keywords: eutrophication; impacts; net cage; oligotrophic; pollution.

Resumo: Objetivo: A aquicultura apresenta grande importância no cenário mundial e brasileiro. A construção artificial de grandes corpos de água, como açudes e reservatórios, aumenta o potencial de cultivo de peixes em tanques-redes nesses ambientes, gerando conflitos sobre o uso dessas águas públicas, onde de um lado está a cadeia produtiva buscando o incremento da produção, e do outro lado o ecossistema, susceptível aos impactos causados pela atividade. O objetivo desta revisão foi levantar questionamentos sobre estes conflitos (produtividade $\times$ ambiente) e indicar possíveis soluçóes para os principais problemas ligados à criação de peixes em tanques-rede em reservatórios. Métodos: $\mathrm{O}$ levantamento bibliográfico abordou os principais aspectos que envolvem a piscicultura em tanques-rede em reservatórios brasileiros. Trabalhos publicados entre 1977 e 2018 (jornais científicos, livros e teses) foram revisados utilizando sete bases indexadoras, os websites "periódicos da capes" e "Google Scholar". As principais palavras-chave utilizadas foram "aquaculture", "reservoir", "cage”, "eutrophication", 
"carrying capacity", “impacts", oligotrophic, "escapes", "hybrids", "pollution”. Resultados: Nesse levantamento foram acessados aproximadamente 330 e citados 151 documentos. Conclusóes: Foram abordados os aspectos negativos associados ao cultivo de peixes em tanques-rede, como os escapes de peixes cultivados, e as possíveis soluçôes deste e de outros impactos negativos, buscando a redução dos conflitos ambientais $v$ s. produção aquícola. Dentre elas, o uso de espécies nativas ou exemplares estéreis, implantação de sistemas de monitoramento da criação e da área do entorno, adoção de medidas que reduzam os escapes acidentais de peixes, uso de sistemas de cultivo multitróficos, utilização de dietas com elevada digestibilidade fornecidas com manejo alimentar apropriado, além do uso de programas computacionais que utilizem dados ambientais atuais e históricos para o cálculo da capacidade de suporte e escolha dos locais mais adequados.

Palavras-chave: eutrofização; impactos; tanque-rede; oligotrófico; poluição.

\section{Introduction}

This review addresses cage fish farming in reservoirs and opportunities to minimize the impacts of this activity. Aquaculture is important globally, with an average annual growth of 5.8 percent between 2005 and 2014 (FAO, 2016). Brazilian aquaculture production has increased during recent years, with a production value of $\mathrm{R} \$ 4.61$ billion in 2016, with most (70.9\%) from fish farming (IBGE, 2017). In addition, according to SOFIA (State of World Fisheries and Aquaculture) reports (FAO, 2016), Brazil will likely sustain growth at $104 \%$ for fishery and aquaculture production until 2025, mainly due to the development of the aquaculture in inland waters. However, although not demonstrated to date, cage fish farming in reservoirs can be an alternative to reduce fishing pressure on natural stocks. The following sections outline several aspects related to cage fish farming systems in reservoirs, focusing mainly on Brazilian conditions.

This review aimed to compile the main studies involving cage fish farming, a subject often polarized and controversial. This activity is not well seen from the perspective of conservation; however, due to the wide availability of reservoirs with large volumes and the possibility to use these areas for aquaculture purpose, we believe that carrying out the activity using best management practices may be the best option for this impasse. Reservoirs with problems associated with aquaculture activity should serve as an example, preventing repetition of errors.

A bibliographical survey was carried out on the main aspects of cage fish farming in Brazilian reservoirs. Studies from 1977 to 2018 (scientific journals, books, and thesis) were reviewed using seven databases (Agris, ASFA, Biosis, CAB, Pubmed/Medline, Scielo and Scopus), CAPES periodicals portal, and Google Scholar websites. The main keywords used were: "aquaculture", "reservoir" "cage", "eutrophication", "carrying capacity", "impacts", "oligotrophic", "escapes", "hybrids", and "pollution". We accessed approximately 330 and cited 151 documents.

\section{Cage Fish Farming}

In Brazil, the emergence of large dams is directly linked to the construction of Hydroelectric Power Plants (HPP). The negative environmental impacts generated by the construction of these dams are large and considered to be proportional to the formation of a new ecosystem, and the main changes affect hydrology, trophic relations, primary production base and nutrient cycling, besides blocking movements of migratory species (Agostinho et al., 2007; Winemiller et al., 2016). Socioeconomic impacts are also an effect of dams, as fishing is hampered by the considerable loss of biodiversity and the change in the prevalence of target species (Brandão et al., 2013). Thus, the production of fish in cages in Brazil has become an alternative for fish production, and it has been implemented in several reservoirs. In addition, the potential profitability of fish farms has caught the attention of government agencies, which encourage and assist in the production process (Queiroz \& Rotta, 2016). Despite the government's support, cage fish farming is a new activity for which a production model still needs to be adapted to reduce costs and make it a sustainable activity (Garcia et al., 2013).

The fish cages can also be placed in ponds, rivers, estuaries and the open ocean. Confining fish in these structures facilitates their observation, feeding and harvesting (Beveridge, 2004; Kumar \& Karnatak, 2014). However, because it is an open system, the interactions that occur in fish cages affect the environment and vice versa, so selecting the location for the cages becomes an important factor (Cardia \& Lovatelli, 2015).

According to Beveridge (2004), there are three main criteria that should be considered when choosing a location: 
- Environmental criteria for fish farming: water quality (dissolved oxygen, temperature, $\mathrm{pH}$, turbidity, pollution), topography, hydrology, and algal blooms;

- Environmental criteria for fish cage structures: climate (precipitation, temperature variations), currents, depth, and substrate;

- Logistical and management criteria: regulations and planning, access, proximity to the consumer market, and security.

Analyses of these criteria are complex and may take a long time to carry out. A Geographical Information System (GIS) is a computer-based tool that uses georeferenced data (remote sensing) that can be used for the evaluation and selection of potential sites for aquaculture (Ross et al., 2011; Pérez et al., 2005). In aquaculture, the data required to execute planning using GIS include economic, social, physical, biological, geographic and sustainability criteria (Meaden \& Aguilar-Manjarrez, 2013). The different sets of data are integrated and overlaid, generating graphs, tables and maps that aid in the analysis for decision-making. For example, the exclusion of protected or contaminated areas, estimation of the maximum number of tanks and the minimum distance between them in each area, and assessment of carrying capacity are factors that help in the development of a management plan to mitigate possible environmental impacts (Serpa \& Duarte, 2008; Meaden \& Aguilar-Manjarrez, 2013).

In Brazil, some studies have already used GIS for locating areas for aquaculture (Völcker \& Scott, 2008; Freitas et al., 2015). However, according to Viann et al. (2016), although the criteria and factors are already established and documented, there are still some difficulties using GIS, such as the need to improve the description of the process for designing decision-making models based on GIS products and enabling a greater number of managers to apply it.

One of the disadvantages of using cages is the operating costs, which are slightly higher when compared to other aquaculture systems such as ponds and raceways. However, the initial costs of implementation are lower and allow a greater number of production cycles (Beveridge, 2004; Baliao \& Dosado, 2011). Another disadvantage of fish cages is that direct contact with the surrounding environment can release leftover food and feces, which impair the quality of the water and the surrounding biota (Serpa \& Duarte, 2008).
Moreover, this direct contact with the environment can also affect fish production, either due to selecting areas that are not suitable for fish farming or because of inadequate management applied within the fish production system.

Referent to the invasive species, another problem that has arisen in cage fish farming is the incrustation of the golden mussel Limnoperna fortunei, a bivalve mollusk (Mytilidae) introduced in Brazil in the 1990's (Pestana et al., 2010). According to Marengoni et al. (2013), the invasion of the golden mussel may impair the great aquaculture potential of the Itaipu reservoir (Paraná River, Paraná, Brazil), if control measures are not taken. Fish cages are an ideal structure for golden mussel fixation, due to the great food supply from the high loads of organic matter produced by the fish in these systems. The fixation of $L$. fortune $i$ in the structures impairs the exchange of water from inside to the outside of the fish cages, preventing the exit of waste products and reducing the oxygenation (Costa et al., 2012; Oliveira et al., 2014). In addition, the shells can cause injuries to fish skin, allowing the access of pathogens and infectious diseases, thus compromising productivity by rising mortality chances (Inoue et al., 2003; Oliveira et al., 2014). The maintenance and cleaning of the fish cages must be more frequent (every 2-3 months) and increase production costs. This management requires labor and the use of high-pressure washers with elevated energy costs. According to producers, stainless steel cages are preferable because they produce less fouling, probably due to the smaller surface of contact, requiring a lower frequency of cleaning and thus reducing management costs (Oliveira et al., 2014).

\section{Water Quality and Environmental Changes}

Cage fish farming can have several negative effects on the water quality of the environment around production. These effects will depend on the species produced, storage density, location, food quality and handling. Nutrients, such as phosphorus and nitrogen, are released into the water column, leading to an increase in nutrient load, which can lead to eutrophication. Ammonia is excreted by the gills and other products of nitrogen and phosphorus are excreted in the feces. Ammonia is the most reactive nitrogen form and is rapidly absorbed by the pelagic microbial community and converted into oxidized forms such as nitrate (Handy \& Poxton, 1993; Black, 2008; Lima et al., 
2018). The release of phosphorus into freshwater environments is a concern because it is generally the most limiting element for algae growth, so its excessive introduction into water bodies can increase algae biomass and lead to harmful blooms, which results in decreased dissolved oxygen levels (Holmer, 2010).

Particulate organic material is mainly from the feed ration not consumed by fish and feces. Approximately 20\% of the food used to feed fish in cages is lost before being ingested (Pearson \& Gowen, 1990), and the rate of dietary utilization by fish grown in cages is $14.8 \%$ for nitrogen and $11 \%$ for phosphorus (Guo \& Li, 2003). Thus, food management is essential to reduce the impact of excess nutrients. To optimize food management, automatic feeders can be used, providing the feed according to defined growth models for the species cultivated (Black, 2008). Increasing feed digestibility is also a feeding strategy, as fish would absorb nutrients more efficiently, reducing the release of waste as well as the production costs (European Commission, 2015; Serpa \& Duarte, 2008). Aquaculture feed is one of the largest expenditures and may exceed $50 \%$ of the total cost of production (Rana et al., 2009).

When an imbalance in the environment occurs and oxygen becomes limiting, geochemical changes in sediment and fauna can be extensive. However, once nutrient introduction from fish farming is ceased, the recovery of the system is relatively fast. This recovery may take several months and be followed by a recolonization of the sediment by a community distinct from the previous one. The process of chemical and biological recovery is closely linked with bioturbation processes, which can result in an increase in the oxygen supply and rapid removal of nitrogen and phosphorus (Black, 2008).

Half of the nutrients supplied to the fish are lost through unconsumed food or fish feces and thus are available for phytoplankton, zooplankton, macroinvertebrates and surrounding fish. The results of a study of different fish species maintained in cages in a Chinese lake demonstrated a strong negative correlation $(r=0.93)$ between phytoplankton biomass and distance from the tanks (Guo \& Li, 2003). Loureiro et al. (2012) observed the increase of zooplankton biomass on the surface of the water near a fish cage in the Itá reservoir located in the Uruguay River (between the states of Santa Catarina and Rio Grande do Sul, Brazil). Tibúrcio et al. (2015) observed an increase in copepod biomass after the installation of tilapia (Oreochromis niloticus) fish cages in the Rosana reservoir on the Paranapanema River (between the states of São Paulo and Paraná, Brazil) and related the increase in biomass to the increase in the concentration of nutrients and changes in environmental variables.

Rosini et al. (2016) observed that tilapia $O$. niloticus cage farming increased water nutrients (mainly ammonium ion and total phosphorus), which changed the phytoplankton community with the increase of Cyanobacterial biomass. Ramos et al. (2013) evaluated the influence of tilapia aquaculture on the feeding habits of several species of fish (Astyanax lacustris = A. altiparanae, Galeocharax knerii, Iheringichthys labrosus, Pimelodus maculatus and Plagioscion squamosissimus). The authors observed among fish with a generalist $\operatorname{diet}$ (A. lacustris, P. maculatus and P. squasissimus) an increase in the condition factor of the fish in the growing areas compared to those in a control area.

Brandão et al. (2014) also evaluate the population of Galeocharax knerii living around cage fish farming activities in the Chavantes reservoir in the Paranapanema River (between the states of São Paulo and Paraná, Brazil), and found that their diet and biological attributes changed due to a greater feeding activity, leading to a higher length, numerical abundance and biomass. On the other hand, severe histophysiological changes were detected in wild Geophagus cf. proximus under the influence of tilapia cage fish farming of the Ilha Solteira Reservoir (located between the states of São Paulo and Mato Grosso do Sul, Brazil), as pancreatic hyperplasia, hepatic functions, possibly interfering with gonadal metabolism and alterations of the liver, when compared to specimens from control area (Kliemann et al., 2018). The use of pharmaceuticals (antibiotics, antiparasitics) is common in fish farming and is mainly used to treat infections and parasitic infestations. The use of these products is recommended because the presence of pathogens negatively affects animal welfare and consequently, productivity.

The main environmental risks associated with the use of chemicals in aquaculture are related to deterioration of water quality, quantity and frequency of use, interference in biogeochemical processes, toxicity to flora and fauna, residence time of the chemical in the environment, development of resistance to pathogenic organisms and reduction of the prophylactic efficiency of therapeutics (Black, 2008; Serpa \& Duarte, 2008). 
The adoption of best management practices (BMPs) helps reduce or eliminate the need for medication use. However, an alternative practice already being widely applied in fish farming is the use of specific vaccines, which has helped reduce the release of pharmaceuticals into the environment, as well as reduce fish mortality and improve their growth (Alderman, 2002; Carpio et al., 2011; European Commission, 2015).

New cultivation methods are being considered to mitigate the impacts of fish farming in cages, such as the culture of shellfish and seaweed alongside or near the net cages. In addition to the benefit of economic diversification, the most important effect is that these organisms absorb nutrients from the system, contributing to the reduction of excess nutrients released from fish production. This method is called integrated multitrophic aquaculture (IMTA), which has garnered attention, as an opportunity to collaborate on sustainable aquaculture (Black, 2008; Troell et al., 2009; European Commission, 2015). For example, an IMTA culture of Nile tilapia $O$. niloticus with the Amazon River prawn Macrobrachiun amazonicum in Brazil reduced phosphorus levels, releasing less phosphorus in effluents and contributing to reduce environmental impacts during the discharge into water bodies (David et al., 2017).

\section{Regulations and Main Species Produced in Fish Cages in Brazil}

According to Gunkel et al. (2015), licenses for aquaculture in Brazil were developed based on three main considerations:

- use of fish cages in $1 \%$ of the water surface area of reservoirs (Interministerial Normative Instruction No. 7/2005);

- minimum depths of $1.75 \mathrm{~m} \times$ the underwater cage construction height; and

- maximum limits for the release of phosphorus and chlorophyll $a$ at $30 \mu \mathrm{g} \mathrm{L}^{-1}$ (Resolution No. 357/2005 of the National Environment Council (Brasil, 2005).

In addition, the licensing system of the National Environmental Council (Resolution No. 413/2009; Brasil, 2009) evaluates the potential impacts of proposed aquaculture enterprises, documents the environmental situation, establishes a minimum criterion for environmental reporting and requires assurance that a monitoring program will be based on hydrobiological studies (Gunkel et al., 2015).
In 2016, Brazilian fish farm production totaled 507 thousand tons, with the cultivation of tilapia mostly produced in cages - making up $47 \%$ of this production. Farms in South and Northeast regions of Brazil were the main tilapia producers (IBGE, 2017). In reservoirs of HPP, tilapia accounts for $90 \%$ of total farmed fish production (Scott, 2013). Tilapia is produced across the world (introduced in over 140 countries), and advantages such as rapid growth, broad tolerance to environmental conditions, and well-established production technology are factors that influence the large-scale production of this species (Canonico et al., 2005; Deines et al., 2016).

Due to its ability to adapt to diverse environmental conditions, tilapia, one of the main escaped species that are non-native in Brazil, may cause a biotic homogenization in the escape region (Daga et al., 2015). Thus, the production of native species is recommended, with investments in studies that improve the feed conversion rates and growth speed of these species, so that producers can be profitable while also stopping production of non-native species (Bezerra \& Angelini, 2016).

Tambaqui, Colossoma macropomum, is the most promising native species cultivated in Brazil and was responsible for $27 \%$ of total fish production in 2016, with higher production in the Northern region (IBGE, 2017). This species occurs naturally in the Amazon and Orinoco River basins and is already adapted to cage fish farming, with a good index of production and high survival rates (Gomes et al., 2010). A feed rate of $1 \%$ of fish body weight per day is considered ideal to maximize the productivity of Tambaqui juveniles created in a fish cage (Chagas et al., 2007), and juveniles can be grown in cages with a volume of 1 or $6 \mathrm{~m}^{3}$ (initial density of $300 \mathrm{fish} / \mathrm{m}^{3}$ ), without zootechnical differences (Gomes et al., 2004). A gradual reduction in the stocking density of Tambaqui is recommended throughout the growing cycle in cages, starting with 300 juveniles $/ \mathrm{m}^{3}$ and reaching $20 \mathrm{fish} / \mathrm{m}^{3}$ to produce $1.0 \mathrm{~kg}$ Tambaquis (Silva \& Fujimoto, 2015). Some studies on the costs of Tambaqui production in fish cages have been performed and indicate a positive economic yield when grown in the Amazon region (Gomes et al., 2006) and in the state of Goiás (Souza et al., 2014).

$\mathrm{Pacu}$, Piaractus mesopotamicus, is a native fish species from the Paraná, Paraguay and Uruguay Basins, with greater distribution in the wetlands of the Central-West region of the Pantanal Mato-grossense (Urbinati et al., 2010). Together 
with Tambaqui, it was considered one of the native species of Brazil with the greatest potential for aquaculture, according to a survey conducted by FAO (Scott, 2013). There are few examples of Pacu production with fish cages. However, promising results have already been reported (Urbinati et al., 2010). Bittencourt et al. (2010) tested the cultivation of Pacu in the transition area of the Itaipu reservoir, used nine fish cages $\left(5 \mathrm{~m}^{3}\right)$ and found that the density of 200 fish/ cage generated the largest productivity. In the same location (Itaipu reservoir), Hilbig et al. (2012) suggested a decrease in $30 \%$ of the total feeding supply for Pacu production in a fish cage. Other studies that guarantee profitability of Pacu production in fish cages located in reservoirs have also been performed, approaching nutrition, production indexes and the minimum scale of Pacu farming (Silva et al., 2012; Signor et al., 2013).

In addition to Tambaqui and Pacu, other native species have also been evaluated for potential production in cages. As an example, the Jundiá, Rhamdia quelen, also known as the silver catfish, which is an omnivorous fish, is widely distributed in South America, and it is considered a species of great commercial interest in southern Brazil (Perdices et al., 2002; Baldisserotto, 2008). Barcellos et al. (2004) tested densities of 100 to 300 juveniles $/ \mathrm{m}^{3}$ in cages for the nursery phase and found mean final weights of 60 and $30 \mathrm{~g}$, respectively. For the grow-out phase of the species, Martinelli et al. (2013) suggest the density of $150 \mathrm{fish} / \mathrm{m}^{3}$ and a feeding frequency of once a day.

Piracanjuba, Brycon orbignyanus (omnivorous species), is widely distributed in the Neotropical region and is one of the six most commercially valuable species in Brazil (Ceccarelli et al., 2010). Beux et al. (2012) have cultivated Piracanjuba in fish cages with different storage densities (50 to $175 \mathrm{fish} / \mathrm{m}^{3}$ ) in the reservoir HPP Machadinho (Uruguay River). The authors indicate that the species did not present good performance indexes, probably due to problems related to size heterogeneity, agonistic behavior and growth stabilization in the winter period. However, due to an economic interest in the species, further studies are still needed to evaluate its cultivation in fish cages, investing, for example, in places with lower temperature fluctuations.

For these colder regions of Brazil, where in addition to the reduction of fish growth there is also a record of fish mortality in the winter period (mainly for Tilapia), the creation of native species from temperate regions may be a solution. It is known that the best growth rates for Tilapia are obtained at temperatures above $27{ }^{\circ} \mathrm{C}$, with a significant reduction in performance at $22^{\circ} \mathrm{C}$ and mortality at $17-18{ }^{\circ} \mathrm{C}$ (Webster \& Lim, 2006). There are promising results from Jundiá ( $R$. quelen) and Suruvi (Steindachneridion scriptum) that tolerate low temperatures and maintain food activity when the water temperature reaches below $15^{\circ} \mathrm{C}$ (Zaniboni-Filho et al., 2009). Some performance results of Jundiá in cages are presented above. Suruvi culture tests were carried out in the Itá reservoir (Uruguay River) and showed that the fish tolerated large variations in water temperature $\left(17\right.$ to $\left.29^{\circ} \mathrm{C}\right)$ and maintained a survival rate of $99 \%$, reaching an average weight of $1.4 \mathrm{~kg}$ at a density of $60 \mathrm{fish} / \mathrm{m}^{3}$ (Nascimento, 2013).

Although the creation of fish with carnivorous habits is less sustainable than omnivores, species such as the Pirarucu, Arapaima gigas, and the Dourado, Salminus brasiliensis, have been studied for cultivation in fish cages. Pirarucu inhabits the waters of the Amazon Basin, and there are little data on its commercial production in cages (Pereira-Filho \& Roubach, 2010). Oliveira et al. (2012) have cultivated Pirarucu in cages $\left(4 \mathrm{~m}^{3}\right)$ in the Sítios Novos Reservoir (Caucaia, Ceará, Brazil) and concluded that the density of $10 \mathrm{fish} / \mathrm{m}^{3}$ is profitable, emphasizing that the high survival rate and fast growth are characteristics that make it a good species for cultivation in this system. Dourado, S. brasiliensis, inhabits Paraná, Paraguay and Uruguay rivers and the basins connected to the Patos Lagoon complex (Weingartner \& Zaniboni-Filho, 2010). Braun et al. (2013) stored Dourado at different densities $\left(0.81\right.$ and $\left.1.63 \mathrm{~kg} / \mathrm{m}^{3}\right)$ in fish cages $\left(1 \mathrm{~m}^{3}\right)$ in the Itá reservoir and found that the different densities did not influence growth. However, the stress parameters evaluated were considered high for the species. Beux et al. (2008) observed that $S$. brasiliensis shows higher growth and survival when fish are reared in cages with higher volumes $\left(8 \mathrm{~m}^{3}\right.$ versus $\left.4 \mathrm{~m}^{3}\right)$ and reduced handling (every 180 days versus every 60 days). Thus, studies are still needed to develop a better protocol for the species.

\section{Ecological Interactions}

Escapes from fish farming are one of the main threats to the biodiversity of native fish species (Orsi \& Agostinho, 1999; Zanatta et al., 2010; Pelicice et al., 2014). Escapes are primarily caused by incidents related to failures in farming equipment 
and their operation (Jensen et al., 2010), and during some management events such as juvenile stocking, harvesting, biometry and length classification (Azevedo-Santos et al., 2011). In cage fish farming, confinement security should be a primary issue, especially when the fish species are exotic, obtained from interspecific crossings or genetically modified.

In recent years, Brazilian aquaculture has had a large increase in the production of hybrid species, resulting from the interspecific and intergenus crosses (Hashimoto et al., 2016). Fish generated by crosses between different species can contaminate natural populations and constitute a significant threat to native wildlife (Agostinho et al., 2007; Hashimoto et al., 2016). Studies have shown that hybrid species may be fertile, and when these species escape, they can breed with native fish, contaminating the genetic diversity of wild populations (Hashimoto et al., 2011; Prado et al., 2012). Accidental escapes are considered "biological pollution" with irreversible ecological and trophic effects (Orsi \& Agostinho, 1999), and social impacts (Naylor et al., 2001). In addition, these introduced species can directly damage the wild fish community, by consuming eggs and larvae of native species (Canonico et al., 2005; Gunkel et al., 2018).

Escapes in fish farming, especially from fish cages, in addition to generating a series of problems to the native ichthyofauna, can be one of the main means of dispersal of exotic species in new environments (Ashikaga et al., 2010). Problems associated with the escape of alien fish can be devastating to native communities, such as the escape of Nile Perch, Lates niloticus, and Nile Tilapia, Oreochromis niloticus, which led to the collapse of native species of the Lake Victoria and Kyoga Lakes (East Africa) (Ogutu-Ohwayo, 1990). These species caused the extinction of most of the native species and consequently resulted in a great social and economic problem in the region. Another example occurred due to the introduction of Cyprinus carpio, Carassius auratus, Lepomis macrochirus and Micropterus salmoides into the Tunal River (Durango, México), resulting in the disappearance of seven native species (Montero Rodríguez, 2005).

Among the measures that can be taken to avoid fish escapes, Jensen et al. (2010) suggest establishing mandatory reporting on all incidents of leakage; mechanisms for analyzing the reports; conducting technical assessments for incidents involving large numbers of fish; introducing a technical standard for cage layouts; and conducting mandatory training for employees. As previously discussed, fish farming escapes from aquaculture stations occur from traditional fish farming and from fish cage systems installed in reservoirs. In excavated tanks, this control is facilitated with suitably sized screens installed at the exit channels of the grow-out ponds; additionally, care is given during cleaning to prevent tanks from overflowing or fish escaping during the handling process. In fish cage systems, care should be even greater since handling is done inside of the reservoir.

In addition to the mentioned measures, the use of an additional safety screen during handling may be a measure used to avoid fish leakage in the fish cage system. An alternative to minimizing impacts from accidental escapes is the use of sterilization technologies on the fish to be farmed (e.g., direct or indirect triploidy). The production of sterile individuals will prevent the escape of fertile individuals able to reproduce and establish in the reservoir. The functional sterility of several species of triploid fish is proven (Tiwary et al., 2004; Melo et al., 2006; Piferrer et al., 2009); however, this guarantee of sterilization of the entire lot of produced fish may vary with the species and the technique employed (Le Curieux-Belfond et al., 2009).

Another option to minimize the risks arising from accidental escapes is the cultivation of monosex lines, using the traditional method for the application of sex hormones, the tetraploidy technique (Garcia et al., 2017), or the production of neomales (Weiss et al., 2017). An additional advantage of monosex cultivation is that several species of fish have different growth potentials between males and females, allowing the fish farmer to exclusively cultivate the genus with greater zootechnical advantage or market value. However, is important to resale that sexual conversion is not entirely safe since there are individuals, at least 3\% are not reverted (Bocek et al., 1992; Phelps \& Cerezo, 1993).

The production of interspecific and intergenus hybrids of fish is one of the most used techniques in global aquaculture, aiming to increase food production, aquarium fish production and recreational fishing (Scribner et al., 2000). These crosses are generated to obtain genetic improvement (Bartley et al., 2001). However, from an ecological point of view, these crosses in freshwater fish farming are a potential threat to the biodiversity of native fish (Helfman, 2007). The problem associated with the use of hybrids has been reported 
by Toledo-Filho et al. (1992), who suggested strict control over hybrid "Tambacu" stocks (crosses between female Colossoma macropomum and male Piaractus mesopotamicus), recommending the adoption of preventive control measures to avoid their spread in the environment. Currently, the production of hybrids in Brazil has reached great proportions, with the intentional production of more than 15 interspecific and intergenus crosses (Hashimoto, 2008; Porto-Foresti et al., 2010), as well as occasional hybrids produced by commercial fish farming, evidenced recently in different species of Jundiá (Rhamdia quelen, R. branneri and $R$. voulezi) (Scaranto et al., 2018).

Molecular analyses have reported that the presence of the first generation of hybrid parental (F1) and genetic introgression of the hybrids Post-F1, resulting from the crosses of Pseudoplatystoma corruscans and $P$. reticulatum, compromise the pure parental lineages in the Upper Paraná River Basin (Prado et al., 2012; Vaini et al., 2014). According to the Brazilian Agricultural Research Corporation (Embrapa, 2012), the production of hybrids stands out for its acceptance among those in the production sector, based on competitiveness and legal liberation, which occurs in some Brazilian states through specific and local legislation: Amapá, Law No. 0066/09-AL, Mato Grosso, Law No. 8464, and São Paulo, Law No. 60582. One way to mitigate the impacts of aquaculture in fish cages is through cultivating pure native species, whose potential has been discussed previously or using lineages of sterile fish. However, further studies need to be conducted to determine how to increase the competitiveness of these native species in relation to the species with the highest current production in Brazil, which is Tilapia. It is important to highlight that the Tilapia lineages used in Brazil are the result of intense genetic improvement, while for the native species a selection process for cultivation does not exist, but wild individuals are randomly chosen. Additionally, as discussed by Zaniboni-Filho (2010), the wide natural distribution of several South American fish species may have promoted distinct populations in different regions or river basins, a condition that allows variation in the zootechnical performance of fish from different populations. This variation, according to the author, serves as the basis for genetic selection of the lineages to be produced under aquaculture conditions.

The ecological processes commonly associated with the introduction and invasion of species are related to predation and competition with native species; however, the introduction of diseases, which despite being subtle, is extremely serious (Britto $\&$ Patrocínio, 2006). The cultivation of fish in cages (both freshwater and sea species), for example, may result in the introduction of allogeneic pathogenic organisms and fish parasites (Frazer, 2009; Nowak, 2007). The introduction of non-native species into a reservoir can result in extraordinary management complications, alterations in the food chain, interactions between species that result in the irreversible dominance of the invasive species, and as already discussed above, the introduction of harmful organisms and parasites (Straškraba et al., 1993; Frazer, 2009). An example occurred with the parasite Bothriocephalus acheilognathi, introduced together with grass carp (Ctenopharyngodon idella) and detected in native fish species in Mexico (Arredondo \& Lozano, 2003; Cardia \& Lovatelli, 2015), as well as the dispersal of Lernaea cyprinacea in several countries due to the introduction of carp for cultivation. Intensive cultivation also increases the risk of disease occurrence, as well as promotes the transfer of parasites to wild populations (Goldburg \& Naylor, 2005). Measures to prevent the spread of diseases involve quarantine and strict sanitary control in the settlement of fish cages, as well as monitoring of the health of the cultivated fish. For the aquaculture industry to maintain control over or prevent the emergence of diseases, a strategy is in development for vaccines and vaccination strategies in fish. Recent biotechnological research has aided in the clarification and control of the pathogenic processes in fish, aiming to diagnose the main diseases, identify virulence factors, characterize isolated and develop vaccines. Although many pathogens already have specific vaccines, such as Streptococcus iniae (Klesius et al., 2000; Locke et al., 2008; Jeong et al., 2016), and Aeromonas salmonicida (Tatner, 1987), there are still several important diseases, mainly of viral and parasitic origin, for which there is no prophylactic treatment (Heppell \& Davis, 2000; Ringø et al., 2014).

Fish may be immunized by injection (usually intraperitoneal), immersion (where animals are immersed in an aqueous solution containing the vaccine antigens), or by oral administration. New technologies such as DNA vaccines have shown promising results as effective strategies to combat viral diseases in fish, protect against multiple diseases in a single injection, and consider the well-being of the animal (Tonheim et al., 2008). The use of immunostimulants, adjutants 
and vaccine transporters in fish culture also offers a wide range of appealing methods to induce and strengthen protection against diseases, helping to reduce losses caused by infectious diseases (Anderson, 1992).

Additional caution should be exercised over the extensive and continuous use of antibiotics, which may lead to the emergence of resistant strains of bacteria (Reinchenbach-Klinke, 1982), in addition to causing environmental contamination with waste disposal. Furthermore, the application of these substances to fish grown in cages makes it difficult to dispose of the medicine in an appropriate place.

Cage fish farming can also enhance interactions between parasites and hosts. Ramos et al. (2014) identified an increase in infections caused by Austrodiplostomum compactum metacercariae in Curvina P. squamosissimus collected close to a cage fish farm in the Chavantes reservoir in the Paranapanema River (between the states of São Paulo and Paraná, Brazil), compared to individuals from a control site. Accord to authors, the presence of cage farm potentiated the infections of metacercariae in Curvina eyes, probably due to the organic enrichment of the sediment and water. Although it does not compromise the size of the fish, the increase in metacercariae in areas with cage systems may increase the possibility of infection in other fish species (Ramos et al., 2014), and can result in serious environmental problems such as the decline of wild populations (Frazer, 2009).

Additionally, the installation of fish cages in reservoirs can also promote the proliferation of the golden mussel L. fortunei, as discussed above. The golden mussel is an important invasive species of South America Rivers, with significant biotic and abiotic changes. This mussel promotes innumerous economic problems in water collection stations, hydroelectric cooling systems, and fish cages (Boltovskoy \& Correa, 2015). Contamination of the environment and dispersal of the golden mussel can occur through the use of fish cages, water for the transport of fish and even handling equipment and contaminated boats. Proper cleaning of fish cages, exposure to air and the use of chlorine to flush structures can prevent the proliferation through the structures.

\section{Environmental Carrying Capacity}

As with aquaculture, all food production systems (agriculture or livestock production) have an environmental impact. Thus, the most relevant factor to evaluate is the ability of the environment to address this impact and prevent degradation (Soto et al., 2013). One of the main challenges for aquaculture in fish cages located in reservoirs is to establish limits that guarantee multiple uses of water and production successes over the long-term in a sustainable way (Garcia et al., 2014).

What is often understood as carrying capacity for aquaculture is the ability to produce a species with a maximum yield, without affecting its growth rates. However, this concept must also be related to the natural resources available for the activity (food, space), the dynamics of the ecosystem involved (organic mineralization capacity and nutrient cycling), financial resources and social and economic effects (Duarte et al., 2003; Serpa \& Duarte, 2008).

The classification of carrying capacity in aquaculture can be defined as (Serpa \& Duarte, 2008; Soto et al., 2013):

- Physical: total area of farms that can be installed in a certain space, with appropriate physical characteristics and that can sustain the activity;

- Production: stocking density of organisms that allows maximum yield;

- Ecological: storage density that can be maintained in the environment without causing damage;

- Economic: biomass amount that investors wish to establish and maintain;

- Social: total activity that society can support without negative social impacts or that the community does not allow.

The carrying capacity of the environment can be calculated with the aid of the GIS program mentioned above in "2. Cage fish farming". The use of this program has grown in recent years, mainly due to the evolution of information technology, the proliferation of the number of available data and increased demand (Meaden \& Aguilar-Manjarrez, 2013).

According to Gunkel et al. (2015), some factors can be considered for calculating the carrying capacity limit, including the discharge rate and reservoir flow, sedimentation rate, reservoir depth and distance between the fish cage and bottom, nutrients concentration (phosphorus and nitrogen) and oxygen concentration. To reduce the damage caused by excess nutrients released during farming, in addition to the production of a feed ration with greater stability and digestibility, settling devices for 
organic matter (feed, excreta) can be implanted just below the tanks and collected by pumping (Serpa \& Duarte, 2008; Gunkel et al., 2015). Both the use of more appropriate diets and the installation of collectors raise production costs and tend to be disregarded by the aquaculture production sector. An alternative that could stimulate the application of best management practices, such as these, is the application of legislation that favors responsible fish farming. Some countries have used a limit on the increase in the concentration of nitrogen in the fish cage culture environment at less than 1\% (Levings, 1994).

When a system operates at its carrying capacity, the environment is susceptible to negative impacts and a sanitary collapse (Garcia et al., 2013). In Brazil, since the establishment of Interministerial Normative Instruction No. 6/2004, which establishes the maximum limit of $1 \%$ of the total area of reservoirs for aquaculture, more than 40 aquaculture parks have already been installed throughout Brazil. For fish cages, the stipulated ratio for an area effectively occupied by fish farms and total area is $1: 8$, and this spacing is estimated as sufficient to dilute the organic load produced by the production process (Brasil, 2004). However, according to Garcia et al. (2014), who performed an experiment with tilapia production in the Ilha Solteira Reservoir (Paraná River, São Paulo / Mato Grosso do Sul, Brazil), this ratio should be $1: 100$. In addition, the authors suggest that the storage density of the fish cages should be reduced to $20 \mathrm{~kg} / \mathrm{m}^{3}$, equivalent to only $1 / 5$ of that currently used by producers in the region $\left(100 \mathrm{~kg} / \mathrm{m}^{3}\right)$. These are some changes that may result in an improvement in all analyzed parameters, indicating values that favor the sustainability of this production system, without affecting the local ecosystem and the environment. One example of efficient improvement of fish production was the use of periphyton-based for Tilapia $O$. niloticus cage culture: bamboo substrate were placed in cages and it was responsible to rise the production up to $52 \mathrm{~kg} / \mathrm{m}^{3}$ (carrying capacity) of tilapia with $32 \%$ less diet in a period $20 \%$ shorter when compared with the treatment without the substrate addition (Garcia et al., 2016). It is worth mentioning the annual fluctuation of the water regime and the temporal variation of the reservoir carrying capacity. There are records in Brazil of production failure of farmed fish in cages due to water stress, such as the failure occurring at a fish farm in the municipality that is the national leading municipality in the production of Tilapia (Jaguaribara, Ceará, Brazil). In 2014, there was a water deficit that caused a reduction of the water level in the Castanhão reservoir, causing the mortality of 3 thousand tons of Tilapia (more than $20 \%$ of the annual production of the municipality), resulting in a decrease in dissolved oxygen concentration. In addition to the direct damages of the activity, this situation causes an environmental imbalance and conflicts with the use of the water resource. Since aquaculture is established as a global industry, a better understanding of its environmental assimilative capacity becomes a fundamental requirement, as is the need to use technologies to reduce its impacts (Black, 2008).

\section{Potential of Oligotrophic Environments}

In many countries, reservoirs are important artificial ecosystems that form a significant component of freshwater resources, as the pace of demand for electricity and water supply is growing. As complex systems, the main problems for reservoirs relate to the need for integrated management of their multiple uses (Henry \& Nogueira, 1999).

The reservoirs can be classified according to their trophic state: oligotrophic, mesotrophic, hypertrophic, dystrophic and calcitrophic (Straškraba et al., 1993). The trophic status of a reservoir may vary depending on the morphological characteristics of each environment; eutrophic regions, mainly in the upper part of the reservoirs, and oligotrophic regions, generally situated in stretches closer to the dam foot (Nogueira et al., 2006). Although primary production in aquatic habitats is based primarily on nitrogen $(\mathrm{N})$ and phosphorus (P) (Esteves, 1988), the trophic state of an environment is not the same as its water quality but is based on several criteria, such as the oxygen curve, composition of substrate or phytoplankton fauna species, concentration of nutrients and various measures of biomass production (Carlson, 1977). In this way, lakes and reservoirs may be considered eutrophic by one criterion while being classified as oligotrophic by another (Carlson, 1977).

Phosphorus, together with nitrogen, are the main elements for the process of eutrophication of lakes and reservoirs (Wetzel, 2001; Pillay, 2004), resulting from excessive organic production inside a reservoir due to the high input of nutrients (Straškraba et al., 1993; Armantrout, 1998). This process can result in algal blooms, toxic algae growth and massive fish mortality (Canonico et al., 2005). 
The contribution of nutrients in a reservoir can come from tributaries of the reservoir, neighboring agricultural production, and aquaculture activities within the reservoir (e.g., fish farming in cages) with their constant input of nutrients, mainly $\mathrm{N}, \mathrm{P}$ and carbon (C) (Tacon \& Forster, 2003).

Although the cultivation in fish cages is responsible for a large contribution of nutrients and is directly associated with processes of eutrophication and environmental impacts, the activity is directly associated with income generation and relevant social importance in many regions of the world (Straškraba et al., 1993). Price et al. (2015) suggested that technological measures, such as feed quality, which improve the absorption of nutrients and generate less waste, can minimize the impacts of fish culture in reservoirs. In experimental fish cages in the Itaipu reservoir, Wolff-Bueno et al. (2008) determined that the concentration of total P did not change, basing this result on local biocenosis. In the Nova Avanhandava reservoir (Tietê River, São Paulo, Brazil), the reduced impact of fish production in cages was associated with the action of local organisms (Ramos et al., 2008).

Considering the impacts related to excess nutrients, oligotrophic reservoirs may present as an alternative. One of the main causes of poor reservoir nutrient richness is the construction of dams upstream, preventing the arrival of nutrients from tributary rivers (Ney, 1996). In addition, variations can be observed along the longitudinal axis of reservoirs, with increased transparency and reduced nutrient concentration, functioning as a substance retention system (Ney, 1996; Nogueira et al., 2006). However, although oligotrophic reservoirs are rarer than eutrophic reservoirs (Kimmel \& Groeger, 1986), these bodies of water are particularly likely to undergo large and rapid reductions in phosphorus concentrations and other nutrients due to their dependence on the quality of the water that comes into the reservoir (Ney, 1996). If oligotrophic (nutrient poor) environments are selected for fish cage facilities, the impacts of aquaculture on the water column may be reduced or minimal (Maldonado et al., 2005). In addition, in oligotrophic environments, rapid dilution may occur with high rates of nutrient recycling in the food web (Machias et al., 2004; Pitta et al., 2006). Considering these factors, the selection of oligotrophic reservoirs for cage fish culture may be an alternative to mitigate the impacts caused by the development of this activity.
Due to multiple uses of reservoirs and the characteristics of each, the selection process for these environments should be thoughtful and avoid compromising cultivation and other uses. In Brazil, the production of fish in cages, in addition to being carried out in reservoirs, is very widespread in areas around dams in the semi-arid region of the Northeast. This is due to the action of the National Department of Drought Works (DNOCS), which began the construction of thousands of dams in northeastern Brazil in 1931 because of the history of severe droughts, resulting in more than 400 large dams. In addition to providing domestic water supply, animal watering, irrigation, fishing, and recreation, these ponds are currently used for Tilapia farming in cages, contributing to income generation for poor rural communities (Dias, 2006). However, these dams present characteristics and restrictions for fish farming. According to local newspapers, inversion of the water column, caused by strong winds in June and July 2015 and 2016, resulted in the mortality of farmed tilapia in the Olho D'água dam in Várzea Alegre (Ceará, Brazil). The reduction of the water level of the dam also led to massive mortalities in the Castanhão reservoir (Jaguaribara, Ceará, Brazil) (IBGE, 2017).

Problems associated with the extrapolation of the carrying capacity of water bodies used for farming fish in cages has also been observed in HPP reservoirs, as is the case of the Itaparica reservoir (São Francisco River, Bahia, Brazil). A modeling study developed by Gunkel et al. (2015) inside the bay of Icó-Mandantes revealed an overload of nutrients due to excess phosphorus, resulting from tilapia farming. Other problems associated with fish culture in cages are related to the use of deep reservoirs, with a reduction of the oxygen level in the warmer months, a $\mathrm{pH}$ increase and redox potential (Monteiro Júnior, 2006). An intensive fish culture system installed in a eutrophic environment further increases nitrogen and phosphorus concentrations in water and sediment, causing deterioration of water quality, mass mortalities and an unfeasible whole farming system (Ramos et al., 2010). High concentrations of nutrients may occur due to nutrient inputs from reservoir margins during rainy periods, even in environments without eutrophication problems (Ferrareze et al., 2005), altering the quality of the water and compromising farming performance, which emphasizes the need for periodic monitoring of the water quality of these systems. 
Another problem resulting from cage fish farming is the accidental escape and the introduction of exotic fish such as tilapia, which, as a species that turns the bottom, tends to increase the turbidity of the water (Attayde et al., 2007), and consequently generate greater expenses for water treatment when the water is intended for human consumption due increases the phytoplankton and cyanobacteria (Lazzaro et al., 2003). The impacts do not account for the previously discussed negative effects on competition and the interaction of the introduced species with the native fish community.

\section{Socioeconomic Impact of Hydroelectric Dams: Fish Farms as an Alternative}

The species of fish that suffer most from modifications caused by the construction of hydroelectric reservoirs are those that have greater longevity and long-distance migratory behavior and have the highest market value (Agostinho et al., 1994). In the new environment formed by the reservoir a proliferation of species with less commercial value occurs and changes the available fishing resources and dynamics of local river fishermen (Hoeinghaus et al., 2009). Fisheries resources are of extreme importance to local populations in some regions of the world, not only because of their economic value but also because they play a key role in the livelihoods and food security of various rural communities. Especially in developing countries, freshwater fisheries are an important source of animal protein and income for local fishermen (Allan et al., 2005). In the Mekong Basin (Asia), for example, where fishing is the main source of animal protein, fishery resources are a crucial source of income for every population living around the basin (Baran \& Myschowoda, 2009).

Hydroelectric dams can collapse populations of migratory fish, blocking their migratory routes and preventing access to their breeding and spawning areas (Dudgeon, 2000). In highly fragmented basins, such as the Paraná River Basin, the modification of environments resulting from river damming caused a drastic change in the species, with the replacement of fish with a high market value, for example, Dourado, S. brasiliensis and Pintado, $P$. corruscans, by species with low commercial value, such as Armado, Pterodoras granulosus, and Corvina, P. squamosissimus (Okada et al., 2005; Hoeinghaus et al., 2009). In these specific cases, where the fish species occurs after the formation of reservoirs, aquaculture in fish cages can be an income and protein alternative for the families of fishermen. However, as cultivation using non-native species promotes a huge risk to native biodiversity (Pelicice et al., 2014), it is recommended that native species and/or sterilized exotic and hybrid fish are used to minimize the impacts resulting from accidental escapes.

\section{Conclusions}

Environmental conflicts related to fish farming in cages in Brazilian reservoirs can be mitigated by taking preventive measures and adopting best management practices. Using native fish species or sterilized non-native or hybrid fish can reduce the environmental risks from accidental escapes. Training personnel involved in preventive actions against accidental escapes, such as the placement of additional screens around the tanks during handling, are actions that can minimize the escape of fish into the environment. The implementation of a continuous system of monitoring for the production and surrounding areas is an important management tool, preventing greater impacts and other uses of the water body. The development and use of balanced and specific feed rations (Bicudo et al., 2012; Cyrino et al., 2012), associated with the adoption of good food management practices is fundamental to reduce the nutrient supply to the environment. There is also an opportunity to remove a portion of these nutrients through the collection of the particulate material that empties from the fish cages. The use of healthy fingerlings raised in multitrophic farming systems are measures that can reduce environmental impacts generated by the activity. Felsing et al. (2005) observed that wild fish population was responsible to consume 40 to $60 \%$ of the nutrients derived from cages stocked with Rainbow Trout Oncorhynchus mykiss, reducing environmental impacts, and concluded that wild fauna should be considered into models which predict the amount waste from cages fish farming. Finally, the selection of suitable areas for cultivation and evaluation of the environmental carrying capacity, including the historical variation of the water dynamics in the environment, are measures that may improve fish farming in cages. Thus, following careful safety measures and management protocols, it is possible to mitigate the environmental problems caused by the current model of fish farming in Brazilian reservoirs.

\section{References}

AgOstinho, A.A., BORghetTi, J.R., VAZZOLER, A.E.A.M. and GOMES, L.C. Itaipu Reservoir: impacts on the ichthyofauna and biological bases for its management. In: UNITED NATIONS 
CENTRE FOR REGIONAL DEVELOPMENT UNCRD, ed. Environmental and social dimensions of reservoir development and management in the $\mathrm{La}$ Plata River Basin. Nagoya: UNCRD, 1994. UNCRD Research Report Series.

AGOSTINHO, A.A., GOMES, L.C. and PELICICE, F.M. Ecologia e manejo de recursos pesqueiros em reservatórios. Maringá: UEM, 2007.

ALDERMAN, D.J. Trends in therapy and prophylaxis 1991-2001. Bulletin of the European Association of Fish Pathologists, 2002, 22, 117-125.

ALLAN, J.D., ABELL, R., HOGAN, Z.E.B., REVENGA, C., TAYLOR, B.W., WELCOMME, R.L. and WINEMILLER, K. Overfishing of inland waters. Bioscience, 2005, 55(12), 1041-1051. http://dx.doi. org/10.1641/0006-3568(2005)055 [1041:OOIW] 2.0.CO;2.

ANDERSON, D.P. Immunostimulants, adjuvants, and vaccine carriers in fish: applications to aquaculture. Annual Review of Fish Diseases, 1992, 2, 281-307. http://dx.doi.org/10.1016/0959-8030(92)90067-8.

ARMANTROUT, N.B. Aquatic habitat inventory terminology. Bethesda: Western Division, American Fisheries Society, 1998.

ARREDONDO, J.L. and LOZANO, S.L. La acuicultura en México. Iztapalapa: Universidad Autónoma Metropolitana, 2003.

ASHIKAGA, F.Y., CASIMIRO, A.C.R., KURCHEVSKI, G., ALMEIDA, F.S. and ORSI, M.L. Invasão dos híbridos em águas continentais brasileiras. Boletim da Associação Brasileira de Limnologia, 2010, 38, 1-4.

ATTAYDE, J.L., OKUN, N., BRASIL, J., MENEZES, R. and MESQUITA, P.D.S. Impactos da introdução da tilápia do Nilo, Oreochromis niloticus, sobre a estrutura trófica dos ecossistemas aquáticos do Bioma Caatinga. Oecologia Brasiliensis, 2007, 11(3), 450461. http://dx.doi.org/10.4257/oeco.2007.1103.13.

AZEVEDO-SANTOS, V.M., RIGOLIN-SÁ, O. and PELICICE, F.M. Growing, losing or introducing? Cage aquaculture as a vector for the introduction of non-native fish in in Furnas Reservoir, Minas Gerais, Brazil. Neotropical Ichthyology, 2011, 9(4), 915-919. http://dx.doi.org/10.1590/S167962252011000400024

BALDISSEROTTO, B. Piscicultura continental no Rio Grande do Sul: situação atual, problemas e perspectivas para o futuro. Ciência Rural, 2008, 39(1), 291-299. http://dx.doi.org/10.1590/S010384782008005000046 .

BALIAO, D.D. and DOSADO, N.S. Tilapia cage farming in freshwater reservoir using artificial diets during dry and wet seasons. Philippine Agricultural Scientist, 2011, 94, 38-39.

BARAN, E. and MYSCHOWODA, C. Dams and fisheries in the Mekong Basin. Aquatic Ecosystem
Health \& Management, 2009, 12(3), 227-234. http:// dx.doi.org/10.1080/14634980903149902.

BARCELLOS, L.J.G., KREUTZ, L.C., QUEVEDO, R.M., FIOREZE, I., CERICATO, L., SOSO, A.B., FAGUNDES, M., CONRAD, J., BALDISSERA, R.K., BRUSCHI, A. and RITTER, F. Nursery rearing of jundiá, (Quoy and Gaimard) in cages: cage type, stocking density and stress response to confinement. Aquaculture, 2004, 232(1-4), 383-394. http://dx.doi.org/10.1016/S0044-8486(03)00545-3.

BARTLEY, P.A., LUTWYCHE, J.K. and GONDA, T.J. Identification and validation of candidate Myb target genes. Blood Cells, Molecules \& Diseases, 2001, 27(2), 409-415. http://dx.doi.org/10.1006/ bcmd.2001.0398. PMid:11259163.

BEUX, L.F., FRACALOSSI, D.M., BROL, F.F., ZANIBONI-FILHO, E. and NUÑER, A.P.O. Criação de Piracanjuba (Brycon orbignyanus) em tanques-rede. In: A.P.O. NUNER and E. ZANIBONI-FILHO, eds. Reservatório de Machadinho: peixes, pesca e tecnologias de criação. Florianópolis: Editora UFSC, 2012, pp. 179-204.

BEUX, L.F., FRACALOSSI, D.M., ZANIBONIFILHO, E., NUNEER, A.P.O. and WEINGARTNER, M. Tecnologia de Produçáo de peixes nativos em tanques-rede nos reservatórios de Machadinho e Itá, Rio Uruguai. In: J.E.P. CYRINO, J.D. SCORVO, L.A. SAMPAIO and R.O. CAVALLI, eds. Tópicos especiais em biologia aquática e aqüicultura II. Jaboticabal: Sociedade Brasileira de Aquicultura e Biologia Aquática, 2008, pp. 53-67.

BEVERIDGE, M.C.M. Cage aquaculture. 3 rd ed. Oxford: Blackwell Publishing, 2004. http://dx.doi. org/10.1002/9780470995761.

BEZERRA, L.A.V. and ANGELINI, R. Aquicultura de tilápia no Brasil: produçáo ilimitada pela ciência. Boletim da Associação Brasileira de Limnologia, 2016, 42, 17-24.

BICUDO, A.D.A., ABIMORAD, E. and CARNEIRO, D. Exigências nutricionais e alimentação do pacu. Nutriaqua: nutrição e alimentação de espécies de interesse para aquicultura brasileira. Florianópolis: Sociedade Brasileira de Aquicultura e Biologia Aquática, 2012, pp. 217-229.

BITTENCOURT, F., FEIDEN, A., SIGNOR, A.A., BOSCOLO, W.R., LORENZ, E.K. and MALUF, M.L.F. Densidade de estocagem e parâmetros eritrocitários de pacus criados em tanques-rede. Revista Brasileira de Zootecnia, 2010, 39(11), 2323-2329. http://dx.doi.org/10.1590/S151635982010001100002 .

BLACK, K.D. Environmental aspects of aquaculture. In: K. CULVER and D. CASTLE, eds. Aquaculture, innovation and social transformation. Switzerland: The International Library of Environmental, Agricultural and Food Ethics, 2008. http://dx.doi. org/10.1007/978-1-4020-8835-3_8. 
BOCEK, A., PHELPS, R.P. and POPMA, T.J. Effect of feeding frequency on sex-reversal and on growth on Nile Tilipia, Oreochromis niloticus. Journal of Applied Aquaculture, 1992, 1(3), 97-103. http://dx.doi. org/10.1300/J028v01n03_09.

BOLTOVSKOY, D. and CORREA, N. Ecosystem impacts of the invasive bivalve Limnoperna fortunei (golden mussel) in South America. Hydrobiologia, 2015, 746(1), 81-95. http://dx.doi.org/10.1007/ s10750-014-1882-9.

BRANDÃO, H., LOBÓN-CERVIÁ, J., RAMOS, I.P., SOUTO, A.C., NOBILE, A.B., ZICA, E.O.P. and CARVALHO, E.D. Influence of a cage farming on the population of the fish species Apareiodon affinis (Steindachner, 1879) in the Chavantes reservoir, Paranapanema River SP/PR, Brazil. Acta Limnologica Brasiliensia, 2013, 24(4), 438-448. http://dx.doi. org/10.1590/S2179-975X2013005000012.

BRANDÃO, H., NOBILE, A.B., SOUTO, A.C., RAMOS, I.P., DE SOUSA, J.Q. and CARVALHO, E.D. Influence of cage fish farming on the diet and biological attributes of Galeocharax knerii in the Chavantes reservoir, Brazil. Boletim do Instituto de Pesca, 2014, 39(2), 157-167.

BRASIL. Instrução Normativa Interministerial n. 6, de 28 de maio de 2004. Diário Oficial da União [da] República Federativa do Brasil, Poder Executivo, Brasília, DF, 31 maio 2004.

BRASIL. Conselho Nacional do Meio Ambiente CONAMA. Resolução no 357, de 17 de março de 2005. Dispóe sobre a classificação dos corpos de água e diretrizes ambientais para o seu enquadramento, bem como estabelece as condiçóes e padróes de lançamento de efluentes, e dá outras providências. Diário Oficial da União [da] República Federativa do Brasil, Poder Executivo, Brasília, DF, 18 mar. 2005.

BRASIL. Conselho Nacional do Meio Ambiente CONAMA. Resolução no 413, de 26 de junho de 2009. Dispóe sobre o licenciamento ambiental da aquicultura, e dá outras providências. Diário Oficial da União [da] República Federativa do Brasil, Poder Executivo, Brasília, DF, 26 jun. 2009.

BRAUN, N., DAFRE, A.L., LIMA, R.L., BEUX, L.F., BROL, F.F. and NUNEER, A.P.O. Growth and stress of dourado cultivated in cages at different stocking densities. Pesquisa Agropecuária Brasileira, 2013, 48(8), 1145-1149. http://dx.doi.org/10.1590/ S0100-204X2013000800050.

BRITTO, M.M. and PATROCÍNIO, D.N.M. A fauna de espécies exóticas no Paraná: contexto nacional e situação atual. In: J.B. CAMPOS, M.G.P. TOSSULINO and C.R.C. MULLER, eds. Unidades de conservação: açóes para valorização da biodiversidade. Curitiba: Instituto Ambiental do Paraná, 2006, pp. 53-94.

CANONICO, G.C., ARTHINGTON, A., MCCRARY, J.K. and THIEME, M.L. The effects of introduced tilapias on native biodiversity. Aquatic Conservation, 2005, 483(5), 463-483. http://dx.doi.org/10.1002/ aqc.699.

CARDIA, F. and LOVATELLI, A. Aquaculture operations in floating HDPE cages: a field handbook. Rome: FAO, 2015. FAO Fisheries and Aquaculture Technical Paper, vol. 593.

CARLSON, R.E. A trophic state index for lakes. Limnology and Oceanography, 1977, 22(2), 361-369. http://dx.doi.org/10.4319/lo.1977.22.2.0361.

CARPIO, Y., BASABE, L., ACOSTA, J., RODRÍGUEZ, A., MENDOZA, A., LISPERGER, A., ZAMORANO, E., GONZÁLEZ, M., RIVAS, M., CONTRERAS, S., HAUSSMANN, D., FIGUEROA, J., OSORIO, V.N., ASENCIO, G., MANCILLA, J., RITCHIE, G., BORROTO, C. and ESTRADA, M.P. Novel gene isolated from Caligus rogercresseyi: a promising target for vaccine development against sea lice. Vaccine, 2011, 29(15), 2810-2820. http://dx.doi.org/10.1016/j. vaccine.2011.01.109. PMid:21320542.

CECCARELLI, P.S., SENHORINI, J.A., CANTELMO, O.A. and REGO, R.F. Piracanjuba (Brycon orbignyanus) (Valencienes, 1849). In: B. BALDISSEROTTO and L.C. GOMES, eds. Espécies nativas para piscicultura no Brasil. 2. ed. Santa Maria: UFSM, 2010, pp. 117-148.

CHAGAS, E.C., GOMES, L.C., MARTINS JÚNIOR, H. and ROUBACH, R. Produtividade de tambaqui criado em tanque-rede com diferentes taxas de alimentação. Ciência Rural, 2007, 37(4), 1109-1115. http://dx.doi.org/10.1590/S010384782007000400031 .

COSTA, J.M., MANSKE, C., SIGNOR, A.A., LUCHESI, J.D., FEIDEN, A. and BOSCOLO, W.R. Incrustação de mexilhão dourado Limnoperna fortunei em tanques-rede. Cultivando o Saber [online], 2012, 5(2), 37-46. [viewed 20 Oct. 2017]. Available from: https://www.fag.edu.br/upload/revista/ cultivando_o_saber/503fb0a040901.pdf

CYRINO, J.E.P., ROUBACH, R. and FRACALOSSI, D.M. Avanços na alimentação e nutrição de peixes carnívoros de água doce. In: D.M. FRACALOSSI and J.E.P. CYRINO, eds. Nutriaqua: nutrição e alimentação de espécies de interesse para a aquicultura brasileira. Florianópolis: Sociedade Brasileira de Aquicultura e Biologia Aquática, 2012, pp. 283-293.

DAGA, V.S., SKÓRA, F., PADIAL, A.A., ABILHOA, V., GUBIANI, E.A. and VITULE, J.R.S. Homogenization dynamics of the fish assemblages in Neotropical reservoirs: comparing the roles of introduced species and their vectors. Hidrobiology, 2015, 746(1), 327-347. http://dx.doi.org/10.1007/ s10750-014-2032-0.

DAVID, F.S., PROENÇA, D.C. and VALENTI, W.C. Phosphorus budget in integrated multitrophic aquaculture systems with Nile Tilapia, Oreochromis 
niloticus, and Amazon River Prawn, Macrobrachium amazonicum. Journal of the World Aquaculture Society, 2017, 48(3), 402-414. http://dx.doi.org/10.1111/ jwas. 12404 .

DEINES, A.M., WITTMANN, M.E., DEINES, J.M. and LODGE, D.M. Tradeoffs among ecosystem services associated with global tilapia introductions. Reviews in Fisheries Science \& Aquaculture, 2016, 24(2), 178-191. http://dx.doi.org/10.1080/23308 249.2015.1115466.

DIAS, J.B. Impactos sócio-econômicos e ambientais da introdução da Tilápia do Nilo, Oreochromis niloticus, em açudes públicos do semi-árido nordestino, Brasil [Dissertação de Mestrado em Meio Ambiente, Cultura e Desenvolvimento]. Natal: Universidade Federal do Rio Grande do Norte, 2006.

DUARTE, P., MENESES, R., HAWKINS, A.J.S., ZHU, M., FANG, J. and GRANT, J. Mathematical modelling to assess the carrying capacity for multispecies culture within coastal waters. Ecological Modelling, 2003, 168(1-2), 109-143. http://dx.doi. org/10.1016/S0304-3800(03)00205-9.

DUDGEON, D. Large-scale hydrological changes in tropical Asia: prospects for riverine biodiversity: the construction of large dams will have an impact on the biodiversity of tropical Asian rivers and their associated wetlands. Bioscience, 2000, 50(9), 793-806. http://dx.doi.org/10.1641/00063568(2000)050[0793:LSHCIT]2.0.CO;2.

EMPRESA BRASILEIRA DE PESQUISA AGROPECUÁRIA - EMBRAPA. Cartilha de genética na piscicultura: importância da variabilidade genética, marcação e coleta para análise de DNA. Brasília: Embrapa, 2012.

ESTEVES, F.D.A. Fundamentos de limnologia. Rio de Janeiro: Interciência, 1988.

EUROPEAN COMMISSION. Science for Environment Policy. Sustainable aquaculture: future brief 11 [online]. Bristol: European Commission DG Environment by the Science Communication Unit, UWE, 2015. [viewed 20 Oct. 2017]. Available from: http://ec.europa.eu/science-environment-policy

FELSING, M., GLENCROSS, B. and TELFER, T. Preliminary study on the effects of exclusion of wild fauna from aquaculture cages in a shallow marine environment. Aquaculture, 2005, 243(14), 159-174. http://dx.doi.org/10.1016/j. aquaculture.2004.09.033.

FERRAREZE, M.F.F., NOGUEIRA, M.G. and VIANNA, N.C. Transporte de nutrientes e sedimentos no rio Paranapanema (SP/PR) e seus principais tributários nas estaçóes seca e chuvosa. In: M.G. NOGUEIRA, R. ENRY and A. JORCIN, eds. Ecologia de reservatórios: impactos potenciais, açóes de manejo e sistemas em cascata. São Carlos: Rima, 2005.
FOOD AND AGRICULTURE ORGANIZATION OF THE UNITED NATIONS - FAO. The state of world fisheries and aquaculture: contributing to food security and nutrition for all. Rome: FAO, 2016.

FRAZER, L. Sea-cage aquaculture, sea lice, and declines of wild fish. Conservation Biology, 2009, 23(3), 599-607. http://dx.doi.org/10.1111/j.15231739.2008.01128.x. PMid:19128323.

FREITAS, R.R., TAGLIANI, P.R.A. and POERSCH, L.H.S. Geoprocessamento aplicado na carcinicultura marinha em São José do Norte, Rio Grande do Sul, Brasil. Revista de Gestão Costeira Integrada, 2015, 15(2), 209-222. http://dx.doi.org/10.5894/rgci548.

GARCIA, F., KIMPARA, J.M., VALENTI, W.C. and AMBROSIO, A. Emergy assessment of tilapia cage farming in a hydroelectric reservoir. Ecological Engineering, 2014, 68, 72-79. http://dx.doi. org/10.1016/j.ecoleng.2014.03.076.

GARCIA, F., ROMERA, D.M., GOZI, K.S., ONAKA, E.M., FONSECA, F.S., SCHALCH, F.S.H.C., CANDEIRA, P.G., GUERRA, L.O.M., CARMO, F.J., CARNEIRO, D.J., MARTINS, M.I.E.G. and PORTELLA, M.C. Stocking density of Nile tilapia in cages placed in a hydroelectric reservoir. Aquaculture, 2013, 410-411, 51-56. http://dx.doi.org/10.1016/j. aquaculture.2013.06.010.

GARCIA, F., ROMERA, D.M., SOUSA, N.S., PAIVA-RAMOS, I. and ONAKA, E.M. The potential of periphyton-based cage culture of Nile tilapia in a Brazilian reservoir. Aquaculture, 2016, 464, 229-235. http://dx.doi.org/10.1016/j. aquaculture.2016.06.031.

GARCIA, S., AMARAL-JÚNIOR, H., YASUY, G.S., LIEBL, F., SOUTO, L.I.M. and ZANIBONIFILHO, E. Tetraploidia em Rhamdia quelen (Quoy e Gaimard, 1824) por choque térmico duplo (quente e frio). Boletim do Instituto de Pesca, 2017, 43(2), 257-265. http://dx.doi.org/10.20950/16782305.2017v43n2p257.

GOLDBURG, R. and NAYLOR, R. Future seascapes, fishing, and fish farming. Frontiers in Ecology and the Environment, 2005, 3(1), 21-28. http://dx.doi. org/10.1890/1540-9295(2005)003[0021:FSFAFF ]2.0.CO;2.

GOMES, L.C., BRANDÃO, F.R., CHAGAS, E.C., FERREIRA, M.F.B. and LOURENÇO, J.N.P. Efeito do volume do tanque-rede na produtividade de tambaqui (Colossoma macropomum) durante a recria. Acta Amazonica, 2004, 34(1), 111-113. http://dx.doi. org/10.1590/S0044-59672004000100014.

GOMES, L.C., CHAGAS, E.C., MARTINS-JUNIOR, H., ROUBACH, R., ONO, A.E. and LOURENÇO, J.N.P. Cage culture of tambaqui (Colossoma macropomum) in a central Amazon floodplain lake. Aquaculture, 2006, 253(1-4), 374-384. http://dx.doi. org/10.1016/j.aquaculture.2005.08.020. 
GOMES, L.C., SIMÓES, L.N. and ARAUJO-LIMA, C.A.R.M. Tambaqui (Colossoma macropomum). In: B. BALDISSEROTTO and L.C. GOMES, eds. Espécies nativas para piscicultura no Brasil. 2. ed. Santa Maria: UFSM, 2010, pp. 174-204.

GUNKEL, G., MATTA, E., SELGE, F., SILVA, G.M.N. and SOBRAL, M.C. Carrying capacity limits of net cage aquaculture in brazilian reservoirs. Revista Brasileira de Ciências Ambientais, 2015, 36(36), 128-144. http://dx.doi.org/10.5327/Z2176947820151008 .

GUNKEL, G., SELGE, F., KEITEL, J., LIMA, D., CALADO, S., SOBRAL, M., RODRIGUEZ, M., MATTA, E., HINKELMANN, R., CASPER, P. and HUPFER, M. Water management and aquatic ecosystem services of a tropical reservoir (Itaparica, São Francisco, Brazil). Regional Environmental Change, 2018, 18(7), 1913-1925. http://dx.doi. org/10.1007/s10113-018-1324-8.

GUO, L. and LI, Z. Effects of nitrogen and phosphorous from fish cage-culture on the communities of a shallow lake in middle Yangtze River basin of China. Aquaculture, 2003, 226(1-4), 201-212. http://dx.doi. org/10.1016/S0044-8486(03)00478-2.

HANDY, R.D. and POXTON, M.G. Nitrogen pollution in mariculture: toxicity and excretion of nitrogenous compounds by marine fish. Reviews in Fish Biology and Fisheries, 1993, 3(3), 205-241. http://dx.doi.org/10.1007/BF00043929.

HASHIMOTO, D.T. Caracterização citogenética e molecular de hibridos interespecificos das espécies Piauç (Leporinus macrocephalus) e Piapara (Leporinus elongatus), utilizados na piscicultura brasileira [Dissertação de Mestrado em Ciências Biológicas]. Botucatu: Universidade Estadual de São Paulo, 2008.

HASHIMOTO, D.T., MENDONÇA, F.F., SENHORINI, J.A., OLIVEIRA, C., FORESTI, F. and PORTO-FORESTI, F. Molecular diagnostic methods for identifying Serrasalmid fish (Pacu, Pirapitinga, and Tambaqui) and their hybrids in the Brazilian aquaculture industry. Aquaculture, 2011,321(1-2), 49-53. http://dx.doi.org/10.1016/j. aquaculture.2011.08.018.

HASHIMOTO, D.T., PRADO, F.D., FORESTI, F. and PORTO-FORESTI, F. Molecular identification of intergenus crosses involving catfish hybrids: Risks for aquaculture production. Neotropical Ichthyology, 2016, 14(2), 1-8. http://dx.doi.org/10.1590/19820224-20150139.

HELFMAN, G.S. Fish conservation: a guide to understanding and restoring global aquatic biodiversity and fishery resources. Washington: Island Press, 2007.

HENRY, R. and NOGUEIRA, M.N. A Represa de Jurumirim (São Paulo): primeira síntese sobre o conhecimento limnológico. In: R. HENRY, ed. Ecologia de reservatórios: estrutura, função e aspectos sociais. Botucatu: Fundibio/Fapesp, 1999.
HEPPELL, J. and DAVIS, H.L. Application of DNA vaccine technology to aquaculture. Advanced Drug Delivery Reviews, 2000, 43(1), 29-43. http:// dx.doi.org/10.1016/S0169-409X(00)00075-2. PMid:10967219.

HILBIG, C.C., BOSCOLO, W.R., FEIDEN, A., DIETERICH, F., LORENZ, E.K. and ZAMINHAN, M. Feeding rate for pacu reared in net cages. Revista Brasileira de Zootecnia, 2012, 41(7), 1570-1575. http://dx.doi.org/10.1590/S151635982012000700003.

HOEINGHAUS, D.J., AGOSTINHO, A.A., GOMES, L.C., PELICICE, F.M., OKADA, E.K., LATINI, J.D., KASHIWAQUI, E.A.L. and WINEMILLER, K.O. Effects of river impoundment on ecosystem services of large tropical rivers: embodied energy and market value of artisanal fisheries. Conservation Biology, 2009, 23(5), 1222-1231. http://dx.doi. org/10.1111/j.1523-1739.2009.01248.x. PMid:19459891.

HOLMER, M. Environmental issues of fish farming in offshore waters: perspectives, concerns and research needs. Aquaculture Environment Interactions, 2010, 1(1), 57-70. http://dx.doi.org/10.3354/aei00007.

INOUE, L.A.K.A., SANTOS-NETO, C. and MORAES, G. Clove oil as anaesthetic for juveniles of matrinxã Brycon cephalus (Gunther, 1869). Ciência Rural, 2003, 33(5), 943-947. http://dx.doi. org/10.1590/S0103-84782003000500023.

INSTITUTO BRASILEIRO DE GEOGRAFIA E ESTATÍSTICA - IBGE. Produção da pecuária municipal 2016. Rio de Janeiro: IBGE, 2017. vol. 44.

JENSEN, Ø., DEMPSTER, T., THORSTAD, E.B., UGLEM, I. and FREDHEIM, A. Escapes of fishes from Norwegian sea-cage aquaculture: causes, consequences and prevention. Aquaculture Environment Interactions, 2010, 1(1), 71-83. http:// dx.doi.org/10.3354/aei00008.

JEONG, Y.U., SUBRAMANIAN, D., YEOUNGHWAN, J., KIM, D.H., PARK, S.H., PARK, K.I., LEE, Y.D. and HEO, M.S. Protective efficiency of an inactivated vaccine against Streptococcus iniae in olive flounder, Paralichthys olivaceus. Archives of Polish Fisheries, 2016, 24(1), 23-32. http://dx.doi. org/10.1515/aopf-2016-0003.

KIMMEL, B.L. and GROEGER, A.W. Limnological and ecological changes associated with reservoir aging. In: G.E. HALL and M.J. VAN DEN AVYLE, eds. Reservoir fisheries management: strategies for the 80's: a National Symposium on Managing Reservoir Fishery Resources. Bethesda: Reservoir Committee Southern Division American Fisheries Society, 1986, pp. 103-109.

KLESIUS, P.H., SHOEMAKER, C.A. and EVANS, J.J. Efficacy of single and combined Streptococcus iniae isolate vaccine administered by intraperitoneal and intramuscular routes in tilapia (Oreochromis niloticus). 
Aquaculture, 2000, 188(3-4), 237-246. http://dx.doi. org/10.1016/S0044-8486(00)00345-8.

KLIEMANN, B.C.K., DELARIVA, R.L., ARRUDA AMORIM, J.P., SILVA RIBEIRO, C., SILVA, B., SILVEIRA, R.V. and RAMOS, I.P. Dietary changes and histophysiological responses of a wild fish (Geophagus cf. proximus) under the influence of tilapia cage farm. Fisheries Research, 2018, 204, 337-347. http://dx.doi.org/10.1016/j.fishres.2018.03.011.

KUMAR, V. and KARNATAK, G. Engineering consideration for cage aquaculture. IOSR Journal of Engineering, 2014, 4, 11-18.

LAZZARO, X., BOUVY, M., RIBEIRO FILHO, R.A., OLIVIERA, V.S., SALES, L.T., VASCONCELOS, A.R. and MATA, M.R. Do fish regulate phytoplankton in shallow eutrophic Northeast Brazilian reservoirs? Freshwater Biology, 2003, 48(4), 649-668. http:// dx.doi.org/10.1046/j.1365-2427.2003.01037.x.

LE CURIEUX-BELFOND, O., VANDELAC, L., CARON, J. and SÉRALINI, G.E. Factors to consider before production and commercialization of aquatic genetically modified organisms: the case of transgenic salmon. Environmental Science \& Policy, 2009, 12(2), 170-189. http://dx.doi.org/10.1016/j. envsci.2008.10.001.

LEVINGS, C.D. Some ecological concerns for net-pen culture of salmon on the coasts of the Northeast Pacific and Atlantic Oceans, with special reference to British Columbia. Journal of Applied Aquaculture, 1994, 4(1), 65-141. http://dx.doi.org/10.1300/ J028v04n01_06.

LIMA, L.B., OLIVEIRA, F.J.M., GIACOMINI, H.C. and LIMA-JUNIOR, D.P. Expansion of aquaculture parks and the increasing risk of non-native species invasions in Brazil. Reviews in Aquaculture, 2018, 10(1), 111-122. http://dx.doi. org/10.1111/raq.12150.

LOCKE, J.B., AZIZ, R.K., VICKNAIR, M.R., NIZET, V. and BUCHANAN, J.T. Streptococcus iniae M-like protein contributes to virulence in fish and is a target for live attenuated vaccine development. PLoS One, 2008, 3(7), e2824. http://dx.doi.org/10.1371/ journal.pone.0002824. PMid:18665241.

LOUREIRO, B.R., BRANCO, C.W.C. and ZANIBONI-FILHO, E. Influence of net-cage fish farming on zooplankton biomass in the Itá reservoir, SC, Brazil. Acta Limnologica Brasiliensia, 2012, 23(4), 357-367. http://dx.doi.org/10.1590/S2179. 975X2012005000014.

MACHIAS, A., KARAKASSIS, I., LABROPOULOU, M., SOMARAKIS, S., PAPADOPOULOU, K.N. and PAPACONSTANTINOU, C. Changes in wild fish assemblages after the establishment of a fish farming zone in an oligotrophic marine ecosystem. Estuarine, Coastal and ShelfScience, 2004, 60(4), 771779. http://dx.doi.org/10.1016/j.ecss.2004.03.014.
MALDONADO, M., CARMONA, M.C., ECHEVERRÍA, Y. and RIESGO, A. The environmental impact of Mediterranean cage fish farms at semi-exposed locations: does it need a re-assessment? Helgoland Marine Research, 2005, 59(2), 121-135. http://dx.doi.org/10.1007/s10152004-0211-5.

MARENGONI, N.G., KLOSOWSKI, E.S., OLIVEIRA, K.P., CHAMBO, A.P.S. and GONÇALVES-JUNIOR, C. Bioacumulação de metais pesados e nutrientes no mexilhão dourado do reservatório da usina hidrelétrica de Itaipu binacional. Química Nova, 2013, 36(3), 359-363. http://dx.doi. org/10.1590/S0100-40422013000300002.

MARTINELLI, S.G., RADUNZ-NETO, J., SILVA, L.P., BERGAMIN, G.T., MASCHIO, D., FLORA, M.A.L.D., NUNES, L.M.C. and POSSANI, G. Densidade de estocagem e frequência alimentar no cultivo de jundiá em tanques-rede. Pesquisa Agropecuária Brasileira, 2013, 48(8), 871-877. http:// dx.doi.org/10.1590/S0100-204X2013000800009.

MEADEN, G.J. and AGUILAR-MANJARREZ, J. Advances in geographic information systems and remote sensing for fisheries and aquaculture. Rome: FAO, 2013. Aquaculture Technical Paper, vol. 552.

MELO, D.C., OLIVEIRA, D.A.A., SOUSA, A.B., CARVALHO, D.C., SEERIG, A.S., CREPALDI, D.V., TEIXEIRA, E.A., RIBEIRO, L.P. and FARIA, P.M.C. Manipulação cromossômica: aplicaçôes práticas na aquacultura. Revista Brasileira de Reprodução Animal, 2006, 30, 105-112.

MONTEIRO JÚNIOR, A.J. Caracterização limnológica e compartimentação do reservatório de Ponte Nova, Alto Tietê, SP: uma contribuição ao seu manejo [Tese de Doutorado em Ciências]. São Paulo: Universidade de São Paulo, 2006.

MONTERO RODRÍGUEZ, M. National aquaculture sector overview: Mexico [online]. Rome: FAO Fisheries and Aquaculture Department, 2005. [viewed 20 Oct. 2017]. Available from: http://www.fao.org/fishery/ countrysector/naso_mexico/en

NASCIMENTO, M.A.P. Densidade de estocagem e temperatura da água na criação de suruvi (Steindachneridion scriptum) em tanques-rede [Dissertação de Mestrado em Aquicultura]. Florianópolis: Universidade Federal de Santa Catarina, 2013.

NAYLOR, R.L., WILLIAMS, S.L. and STRONG, D.R. Ecology. Aquaculture: a gateway for exotic species. Science, 2001, 294(5547), 1655-1656. http://dx.doi. org/10.1126/science.1064875. PMid:11721035.

NEY, J.J. Oligotrophication and its discontents: effects of reduced nutrient loading on reservoir fisheries. American Fisheries Society Symposium, 1996, 16, 285-295. 
NOGUEIRA, M.G., JORCIN, A., VIANNA, N.C. and BRITTO, Y.C.T. Reservatórios em cascata e os efeitos na limnologia e organizaçáo das comunidades bióticas (fitoplâncton, zooplâncton e zoobentos): um estudo de caso no rio Paranapanema (SP/PR). In: M.G. NOGUEIRA, R. HENRY and A. JORCIN, eds. Ecologias de reservatórios: impactos potenciais, açôes de manejo e sistema em cascata. São Carlos: RiMa, 2006, pp. 435-459.

NOWAK, B.F. Parasitic diseases in marine cage culture: an example of experimental evolution of parasites? International Journal for Parasitology, 2007, 37(6), 581-588. http://dx.doi.org/10.1016/j. ijpara.2007.01.003. PMid:17316650.

OGUTU-OHWAYO, R. The decline of the native fishes of lakes Victoria and Kyoga (East Africa) and the impact of introduced species, especially the Nile perch, Lates niloticus, and the Nile tilapia, Oreochromis niloticus. Environmental Biology of Fishes, 1990, 27(2), 81-96. http://dx.doi.org/10.1007/ BF00001938.

OKADA, E.K., AGOSTINHO, A.A. and GOMES, L.C. Spatial and temporal gradients in artisanal fisheries of a large Neotropical reservoir, the Itaipu Reservoir, Brazil. Canadian Journal of Fisheries and Aquatic Sciences, 2005, 62(3), 714-724. http://dx.doi. org/10.1139/f05-015.

OLIVEIRA, E.G., PINHEIRO, A.B., OLIVEIRA, V.Q., SILVA-JÚNIOR, A.R.M., MORAES, M.G., ROCHA, I.R.C.B., SOUSA, R.R. and COSTA, F.H.F. Effects of stocking density on the performance of juvenile pirarucu (Arapaima gigas) in cages. Aquaculture, 2012, 370-371, 96-101. http://dx.doi. org/10.1016/j.aquaculture.2012.09.027.

OLIVEIRA, M.D., AYROZA, D.M.R., CASTELLANI, D., CAMPOS, M.C.S. and MANSUR, M.C.D. O mexilhão dourado nos tanques-rede das pisciculturas das Regióes Sudeste e Centro-oeste. Panorama da Aquicultura, 2014, 145, 22-29.

ORSI, M.L. and AGOSTINHO, A.A. Introdução de espécies de peixes por escapes acidentais de tanques de cultivo em rios da Bacia do Rio Paraná, Brasil. Revista Brasileira de Zoologia, 1999, 16(2), 557-560. http:// dx.doi.org/10.1590/S0101-81751999000200020.

PEARSON, T.H. and GOWEN, R.J. Impact of caged fish farming on the marine environment: the Scottish experience. In: P. OLIVER and E. COLLERAN, eds. Interation between aquaculture and environment. Dublin: An Taise, The National Trust for Ireland, 1990. pp. 9-13.

PELICICE, F.M., VITULE, J.R.S., LIMA JUNIOR, D.P., ORSI, M.L. and AGOSTINHO, A.A. A serious new threat to Brazilian freshwater ecosystems: the naturalization of nonnative fish by decree. Conservation Letters, 2014, 7(1), 55-60. http://dx.doi. org/10.1111/conl.12029.
PERDICES, A., BERMINGHAM, E., MONTILLA, A. and DOADRIO, I. Evolutionary history of the genus Rhamdia (Teleostei: Pimelodidae) in Central America. Molecular Phylogenetics and Evolution, 2002, 25(1), 172-189. http://dx.doi.org/10.1016/S10557903(02)00224-5. PMid:12383759.

PEREIRA-FILHO, M. and ROUBACH, R. Pirarucu (Arapaima gigas). In: B. BALDISSEROTTO and L.C. GOMES, eds. Espécies nativas para piscicultura no Brasil. 2. ed. Santa Maria: UFSM, 2010, pp. 27-56.

PÉREZ, O.M., TELFER, T.C. and ROSS, L.G. Geographical information systems-based models for offshore floating marine fish cage aquaculture site selection in Tenerife, Canary Islands. Aquaculture Research, 2005, 36(10), 946-961. http://dx.doi. org/10.1111/j.1365-2109.2005.01282.x.

PESTANA, D., OSTRENSKY, A., TSCHÁ, M.K. and BOEGER, W.A. Prospecção do molusco invasor Limnoperna fortunei (Dunker, 1857) nos principais corpos hídricos do estado do Paraná, Brasil. Papéis Avulsos de Zoologia, 2010, 50(34), 553-559. http:// dx.doi.org/10.1590/S0031-10492010003400001.

PHELPS, R.P. and CEREZO, G. The effect of confinement in hapas on sex reversal and growth of Oreochronmis niloticus. Journal of Applied Aquaculture, 1993, 1(4), 73-82. http://dx.doi.org/10.1300/ J028v01n04_06.

PIFERRER, F., BEAUMONT, A., FALGUIÈRE, J.C., FLAJSHANS, M., HAFFRAY, P. and COLOMBO, L. Polyploid fish and shellfish: production, biology and applications to aquaculture for performance improvement and genetic containment. Aquaculture, 2009, 293(3-4), 125-156. http://dx.doi. org/10.1016/j.aquaculture.2009.04.036.

PILLAY, T.V.R., ed. Aquaculture and the environment. 2nd ed. United Kingdom: Blackwell Publishing, 2004. http://dx.doi.org/10.1002/9780470995730.

PITTA, P., APOSTOLAKI, E.T., TSAGARAKI, T., TSAPAKIS, M. and KARAKASSIS, I. Fish farming effects on chemical and microbial variables of the water column: a spatio-temporal study along the Mediterranean Sea. Hydrobiologia, 2006, 563(1), 99108. http://dx.doi.org/10.1007/s10750-005-1593-3.

PORTO-FORESTI, F., HASHIMOTO, D.T., SEHORINI, J.A. and FORESTI, F. Hibridação em piscicultura: monitoramento e perspectivas. In: B. BALDISSEROTTO and L.C. GOMES, eds. Espécies nativas para piscicultura no Brasil. 2. ed. Santa Maria: UFSM, 2010, pp. 589-606.

PRADO, F.D., HASHIMOTO, D.T., SENHORINI, J.A., FORESTI, F. and PORTO-FORESTI, F. Detection of hybrids and genetic introgression in wild stocks of two catfish species (Siluriformes: Pimelodidae): the impact of hatcheries in Brazil. Fisheries Research, 2012, 125-126, 300-305. http:// dx.doi.org/10.1016/j.fishres.2012.02.030. 
PRICE, C., BLACK, K.D., HARGRAVE, B.T. and MORRIS JUNIOR, J.A. Marine cage culture and the environment: effects on water quality and primary production. Aquaculture Environment Interactions, 2015, 6(2), 151-174. http://dx.doi.org/10.3354/ aei00122.

QUEIROZ, J.F. and ROTTA, M.A. Boas práticas de manejo para piscicultura em tanques-rede. Jaguariúna: Embrapa Meio Ambiente, 2016. Circular Técnica, no. 26.

RAMOS, I.P., BRANDÁO, H., ZANATTA, A.S., ZICA, É.D.O.P., DA SILVA, R.J., DE REZENDEAYROZA, D.M.M. and CARVALHO, E.D. Interference of cage fish farm on diet, condition factor and numeric abundance on wild fish in a Neotropical reservoir. Aquaculture, 2013, 414-415, 56-62. http:// dx.doi.org/10.1016/j.aquaculture.2013.07.013.

RAMOS, I.P., FRANCESCHINI, L., ZICA, É.O., CARVALHO, E.D. and SILVA, R.J. The influence of cage farming on infection of the corvine fish Plagioscion squamosissimus (Perciformes: Sciaenidae) with metacercariae of Austrodiplostomum compactum (Digenea: Diplostomidae) from the Chavantes reservoir, São Paulo State, Brazil. Journal of Helminthology, 2014, 88(3), 342-348. http://dx.doi.org/10.1017/S0022149X13000229. PMid:23628163.

RAMOS, I.P., VIDOTTO-MAGNONI, A.P. and CARVALHO, E.D. Influence of cage fish farming on the diet of dominant fish species of a Brazilian reservoir (Tietê River, High Paraná River basin). Acta Limnologica Brasiliensia, 2008, 20(3), 245-252.

RAMOS, I.P., ZANATTA, A.S., ZICA, E.O.P., SILVA, R.J. and CARVALHO, E.D. Impactos ambientais de pisciculturas em tanques-rede sobre águas continentais brasileiras: revisão e opinião. In: J.E.P. CYRINO, W.M. FURUYA, R.P. RIBEIRO and J.D. SCORVO FILHO, eds. Tópicos especiais em biologia aquática e aquicultura III. Jaboticabal: Sociedade Brasileira de Biologia Aquática, 2010, pp. 87-98.

RANA, K.J., SIRIWARDENA, S. and HASAN, M.R. Impact of rising feed ingredient prices on aquafeeds and aquaculture production. Rome: FAO, 2009. FAO Fisheries and Aquaculture Technical Paper, vol. 541.

REINCHENBACH-KLINKE, H.H. Enfermidades de los peces. Zaragoza: Editorial Acribia, 1982.

RINGØ, E., OLSEN, R.E., JENSEN, I., ROMERO, J. and LAUZON, H.L. Application of vaccines and dietary supplements in aquaculture: possibilities and challenges. Reviews in Fish Biology and Fisheries, 2014, 24(4), 1005-1032. http://dx.doi.org/10.1007/ s11160-014-9361-y.

ROSINI, E.F., TUCCI, A., DO CARMO, C.F., ROJAS, N.E.T., BARROS, H.P. and MALLASEN, $M$. Changes in phytoplankton spatial and temporal dynamics in a Brazilian tropical oligotrophic reservoir after net cage installation. Brazilian Journal of Botany,
2016, 39(2), 569-581. http://dx.doi.org/10.1007/ s40415-016-0259-x.

ROSS, L.G., FALCONER, L.L., CAMPOS MENDOZA, A. and MARTINEZ PALACIOS, C.A. Spatial modelling for freshwater cage location in the Presa Adolfo Mateos Lopez (El Infiernillo), Michoacán, México. Aquaculture Research, 2011, 42(6), 797-807. http://dx.doi.org/10.1111/j.13652109.2010.02689.x

SCARANTO, B.M.S., RIBOLLI, J. and ZANIBONIFILHO, E. DNA barcoding reveals blend of silver catfish Rhamdia species from fish farms in Southern Brazil. Aquaculture Research, 2018, 49(5), 1907. 1913. http://dx.doi.org/10.1111/are.13646.

SCOTT, P.C. Regional and national factors relevant to site selection for aquaculture in the Federative Republic of Brazil. In: L.G. ROSS, T.C. TELFER and L. FALCONER, eds. Site selection and carrying capacities for inland and coastal aquaculture. Rome: FAO, 2013, pp. 263-270. FAO Fisheries and Aquaculture Proceedings, vol. 21.

SCRIBNER, K.T., PAGE, K.S. and BARTRON, M.L. Hybridization in freshwater fishes: a review of case studies and cytonuclear methods of biological inference. Reviews in Fish Biology and Fisheries, 2000, 10(3), 293-323. http://dx.doi. org/10.1023/A:1016642723238.

SERPA, D. and DUARTE, P. Impacts of aquaculture and mitigation measures. Dynamic Biochemistry, Process Biotechnology and Molecular Biology, 2008, 2, 1-20.

SIGNOR, A.A., POTRICH, F.R., FEIDEN, A., BOSCOLO, W.R., RIBEIRO, R.P. and VARGAS, L. Vitamina A em dieta de juvenis de pacu cultivados em tanques-rede. Pesquisa Agropecuária Brasileira, 2013, 48(8), 1103-1109. http://dx.doi.org/10.1590/ S0100-204X2013000800041.

SILVA, C.A. and FUJIMOTO, R.Y. Crescimento de tambaqui em resposta a densidade de estocagem em tanques-rede. Acta Amazonica, 2015, 45(3), 323-332. http://dx.doi.org/10.1590/1809-4392201402205.

SILVA, J.R., RABENSCHLAG, D.R., FEIDEN, A., BOSCOLO, W.R., SIGNOR, A.A. and BUENO, G.W. Produção de pacu em tanques-rede no reservatório de Itaipu, Brasil: retorno econômico. Archivos de Zootecnia, 2012, 61(234), 245-254. http:// dx.doi.org/10.4321/S0004-05922012000200009.

SOTO, D., WHITE, P. and ISYAGI, N. Environmental management and environmental impacts assessment for aquaculture managers. Ebene: FAO-SmartFish Programme of the Indian Ocean Comission, 2013. Report: SF-FAO/2013/19.

SOUZA, R.A., MACHADO, D., PADUA, C., PRISCILA, R., OLIVEIRA, D.C., CESAR, T. and MAIA, B. Análise econômica da criação de tambaqui em tanques-rede: estudo de caso em assentamento da 
reforma agrária. Custos e Agronegócio, 2014, 10(1), 253-268.

STRAŠKRABA, M., TUNDISI, J.G. and DUNCAN, A. State of the art of reservoir limnology and water quality management. In: M. STRAŠKRABA, J.G. TUNDISI and A. DUNCAN, eds. Comparative reservoir limnology and water quality management. Netherlands: Springer, 1993, pp. 213-288. http:// dx.doi.org/10.1007/978-94-017-1096-1_13.

TACON, A.G.J. and FORSTER, I.P. Aquafeeds and the environment: policy implications. Aquaculture, 2003, 226(1-4), 181-189. http://dx.doi.org/10.1016/ S0044-8486(03)00476-9.

TATNER, M.F. The quantitative relationship between vaccine dilution, length of immersion time and antigen uptake, using a radiolabelled Aeromonas salmonicida bath in direct immersion experiments with rainbow trout, Salmo gairdneri. Aquaculture, 1987, 62(3-4), 173-185. http://dx.doi.org/10.1016/00448486(87)90164-5.

TIBÚRCIO, V.G., ARRIEIRA, R.L., SCHWIND, L.T.F., BONECKER, C.C. and LANSACTÔHA, F.A. Effects of nutrients increase on the copepod community of a reservoir using cages. Acta Limnologica Brasiliensia, 2015, 27(3), 265-274. http://dx.doi.org/10.1590/S2179-975X0315.

TIWARY, B.K., KIRUBAGARAN, R. and RAY, A.K. The biology of triploid fish. Reviews in Fish Biology and Fisheries, 2004, 14(4), 391-402. http://dx.doi. org/10.1007/s11160-004-8361-8.

TOLEDO-FILHO, S.A., ALMEIDA-TOLEDO, L.F., FORESTI, F., GALHARDO, E. and DONOLA, E. Conservação genética de peixes em projetos de repovoamento de reservatórios. São Paulo: USP, 1992. Cadernos de Ictiogenética, vol. 1.

TONHEIM, T.C., BØGWALD, J. and DALMO, R.A. What happens to the DNA vaccine in fish? A review of current knowledge. Fish \& Shellfish Immunology, 2008, 25(1-2), 1-18. http://dx.doi.org/10.1016/j. fsi.2008.03.007. PMid:18448358.

TROELL, M., JOYCE, A., CHOPIN, T., NEORI, A., BUSCHMANN, A.H. and FANG, J.G. Ecological engineering in aquaculture: potential for integrated multi-trophic aquaculture (IMTA) in marine offshore systems. Aquaculture, 2009, 297(1-4), 1-9. http:// dx.doi.org/10.1016/j.aquaculture.2009.09.010.

URBINATI, E.C., GONÇALVES, F.D. and TAKASHI, L.S. Pacu (Piaractus mesopotamicus). In: B. BALDISSEROTTO and L.C. GOMES, eds. Espécies nativas para piscicultura no Brasil. 2. ed. Santa Maria: UFSM, 2010, pp. 205-244.

VAINI, J.O., GRISOLIA, A.B., PRADO, F.D.D. and PORTO-FORESTI, F. Genetic identification of interspecific hybrid of Neotropical catfish species (Pseudoplatystoma corruscans vs. Pseudoplatystoma reticulatum) in rivers of Mato Grosso do Sul State,
Brazil. Neotropical Ichthyology, 2014, 12(3), 635-641. http://dx.doi.org/10.1590/1982-0224-20130169.

VIANN, L.F., BONETTI, J. and BONETTI, C. Sistemas de informaçóes geográficas para seleção de sítios para aquicultura: uma revisão. Revista Agropecuária Catarinense, 2016, 29(2), 90-95.

VÖLCKER, C.M. and SCOTT, P. SIG e sensoriamento remoto para a determinação do potencial da aqüicultura no baixo São João - RJ. Revista Eletrônica Sistemas \& Gestäo, 2008, 3, 196-215.

WEBSTER, C.D. and LIM, C. Tilapia: biology, culture and nutrition. Binghamtom: Food Products Press, 2006.

WEINGARTNER, M. and ZANIBONI-FILHO, E. Biologia e cultivo do dourado. In: B. BALDISSEROTTO and L.C. GOMES, eds. Espécies nativas para piscicultura no Brasil. 2. ed. Santa Maria: UFSM, 2010, pp. 245-281.

WEISS, L.A., BERNARDES JÚNIOR, J. and NUNER, A.P.O. Identification of neomales in South American catfish Rhamdia quelen on the basis of the sex ratio in the progeny. Animal Reproduction, 2017, 14, 1285-1291, Supplement 1. http://dx.doi. org/10.21451/1984-3143-AR0031.

WETZEL, R.G. Limnology: lake and river ecosystems. Texas: Gulf Professional Publishing, 2001.

WINEMILLER, K.O., MCINTYRE, P.B., CASTELLO, L., FLUET-CHOUINARD, E., GIARRIZZO, T., NAM, S., BAIRD, I.G., DARWALL, W., LUJAN, N.K., HARRISON, I., STIASSNY, M.L.J., SILVANO, R.A.M., FITZGERALD, D.B., PELICICE, F.M., AGOSTINHO, A.A., GOMES, L.C., ALBERT, J.S., BARAN, E., PETRERE, M., ZARFL, C., MULLIGAN, M., SULLIVAN, J.P., ARANTES, C.C., SOUSA, L.M., KONING, A.A., HOEINGHAUS, D.J., SABAJ, M., LUNDBERG, J.G., ARMBRUSTER, J., THIEME, M.L., PETRY, P., ZUANON, J., TORRENTE VILARA, G., SNOEKS, J., OU, C., RAINBOTH, W., PAVANELLI, C.S., AKAMA, A., VAN SOESBERGEN, A. and SÁENZ, L. Balancing hydropower and biodiversity in the Amazon, Congo, and Mekong: basin-scale planning is needed to minimize impacts in mega-diverse rivers. Science Development and Environment, 2016, 351(6269), 128-129.

WOLFF-BUENO, G., GARCIA MARENGONI, N., GONÇALVES JÚNIOR, A.C., ROGÉRIO BOSCOLO, W. and TEIXEIRA, R.D.A. Estado trófico e bioacumulação do fósforo total no cultivo de peixes em tanques-rede na área aquícola do reservatório de Itaipu. Acta Scientiarum. Biological Sciences, 2008, 30(3), 237-243.

ZANATTA, A.S., RAMOS, I.P., SILVA, R.J., LANGEANI, F. and CARVALHO, E.D. Pisces, Siluriformes, Ictaluridae, Ictalurus punctatus (Rafinesque, 1818): first record in middle 
Paranapanema river reservoir, aquaculture and exotic species dispersion. Check List, 2010, 6(4), 589-591. http://dx.doi.org/10.15560/6.4.589.

ZANIBONI FILHO, E. Piscicultura amazônica: potencialidades e desafios para o desenvolvimento em rede. In: J. NÚNEEZ, F. CHU-KOO, J. PORTO and C. GARCÍA-DÁVILA, eds. Biología de las Poblaciones de Peces de la Amazonía y Piscicultura: Comunicaciones del Segundo Coloquio Internacional de la Red de
Investigación sobre la Ictiofauna Amazónica (RIIA). Manaus: INPA, 2010.

ZANIBONI FILHO, E., WEINGARTNER, M., BEUX, L.F. and NUNEER, A.P.O. Espécies nativas com potencial para regióes de clima frio. Panorama da Aquicultura, Rio de Janeiro, RJ, 31 ago. 2009.

Received: 21 November 2017 Accepted: 03 October 2018. 